\title{
Structural Evolution of Molten Slag during the Early Stage of Basic Oxygen Steelmaking
}

\author{
Rui ZHANG, ${ }^{1,2)}$ Yi MIN, ${ }^{1,2) *}$ Yu WANG, ${ }^{1,2)}$ Xuan $\mathrm{ZHAO}^{1,2)}$ and Chengjun LIU ${ }^{1,2)}$ \\ 1) Key Laboratory for Ecological Metallurgy of Multimetallic Ores (Ministry of Education), Shenyang, 110819 China. \\ 2) School of Metallurgy, Northeastern University, Shenyang, 110819 China.
}

(Received on July 3, 2019; accepted on August 19, 2019)

\begin{abstract}
The better understanding of structural effect of composition is of primary importance in the design of converter slag and for rationalizing the foaming performance of smelting process. In the present work, the $\mathrm{CaO}-\mathrm{SiO}_{2}-\mathrm{Fe}_{x} \mathrm{O}$ samples with different compositions were prepared to simulate the converter slag of initial smelting stage. The compositions and structural units of slag samples were investigated by combining $X$-ray fluorescence spectroscopy and Raman spectroscopy. According to the results, the transformation behaviors of structural units and the degree of polymerization (DOP) of molten slag were further analyzed. The results of Raman spectra showed that when basicity increased from 0.38 to 0.97 and total iron content decreased from 32.77 to 13.26 mass $\%$, increasing $\mathrm{O}^{2-}$ led to the depolymerization of $\left[\mathrm{SiO}_{4}\right]^{4-}$ tetrahedrons from $\mathrm{Q}^{3}$ to $\mathrm{Q}^{0}$ units and the increasing $\left[\mathrm{FeO}_{4}\right]^{5-} /\left[\mathrm{FeO}_{6}\right]^{9-}$ ratio. With further increasing basicity from 0.97 to $1.25, \mathrm{Q}^{3}$ units disappeared and more $\mathrm{O}^{2-}$ reacted with $\left[\mathrm{FeO}_{4}\right]^{5-}$ tetrahedrons to form $\left[\mathrm{FeO}_{6}\right]^{9-}$ octahedrons. Meanwhile, $\mathrm{Fe}^{3+}$ could probably form $\mathrm{Si}-\mathrm{O}-\mathrm{Fe}$ bond by replacing $\mathrm{Si}^{4+}$ cations in $\mathrm{Q}^{3}$ units. Overall, the depolymerization of $\left[\mathrm{SiO}_{4}\right]^{4-}$ tetrahedrons from $\mathrm{Q}^{3}$ to $\mathrm{Q}^{0}$ units was the main reason for the decreasing DOP of molten slag during the early stage of basic oxygen steelmaking.
\end{abstract}

KEY WORDS: basic oxygen steelmaking; molten slag; melt structure; evolution.

\section{Introduction}

Basic oxygen steelmaking is the most important manufacturing method used as steel primary smelting with satisfactory metallurgical quality and productivity in the world. During the primary steelmaking process, converter slag plays a crucial role in the elimination of impurity elements (desiliconization, dephosphorization and decarbonization), controlling of reaction efficiency and the smelting stability related to the active multiphase reaction among molten slag, liquid steel and gas. ${ }^{1-3)}$ As far as the early smelting stage is concerned, the moderate foaming of converter slag is encouraged to facilitate the reaction of molten slag and improve the metallurgical safety by preventing molten slag from overflowing or splashing., ${ }^{4,5}$

In order to modify the foaming behavior of metallurgical slag, numerous studies have been carried out. Cooper and Kitchener $^{6}$ first proposed that the foam stability of molten slag could be described in terms of "foam life". For iron-free $\mathrm{CaO}-\mathrm{SiO}_{2}-\mathrm{P}_{2} \mathrm{O}_{5}$ slags, the research ${ }^{6)}$ showed that foam life increased with increasing $\mathrm{P}_{2} \mathrm{O}_{5}$ content and basicity. For iron-bearing $\mathrm{CaO}-\mathrm{SiO}_{2}-\mathrm{FeO}$ slags, Ito et al. ${ }^{7)}$ showed that foam life decreased with increasing basicity, but foam life could increase when basicity was greater than 1.2. Hara et al. ${ }^{8)}$ reported that the addition of $\mathrm{P}_{2} \mathrm{O}_{5}, \mathrm{Na}_{2} \mathrm{O}$ and $\mathrm{CaF}_{2}$ also contributed to increase in foam life of $\mathrm{CaO}-\mathrm{SiO}_{2}-\mathrm{FeO}$

\footnotetext{
* Corresponding author: E-mail: miny@mail.neu.edu.cn DOI: https://doi.org/10.2355/isijinternational.ISIJINT-2019-413
}

slags, but addition of 10 mass $\% \mathrm{MgO}$ had no effect on foam stability. Whereas Fruehan et al. ${ }^{9)}$ thought that foam life increased with increasing $\mathrm{MgO}$. Although foam stability of molten slag is susceptible to be affected by its composition, the foaming behavior of molten slag is determined by melt structure in essence.

In the previous studies, the foaming behavior of molten slag was only described qualitatively on the basis of varying compositions. In order to design the converter slag with a suitable foaming capacity, structural behaviors of molten slag must be further analyzed. At present, the structural behaviors of alkali and alkaline earth metals in converter slag are explicit, e.g., calcium and magnesium mainly serve as network modifiers. ${ }^{10)}$ And the structural behavior of silicon is also clear, which acts as a network former. ${ }^{11)}$ However, other important components of converter slag (Fe, $\mathrm{P}$ and $\mathrm{Al}$ ) perform more complicated structure behaviors. For example, the valence values of iron ions are not fixed. Even though the valence values of iron ions are identical, different structural types are formed by iron. Mysen ${ }^{12)}$ and $\mathrm{Virgo}^{13)}$ thought that ferric ions behaved as network formers as well as network modifiers in the $\mathrm{SiO}_{2}-\mathrm{Al}_{2} \mathrm{O}_{3}-\mathrm{Fe}_{2} \mathrm{O}_{3}-$ $\mathrm{CaO}-\mathrm{MgO}-\mathrm{Na}_{2} \mathrm{O}$ system, and ferrous ions only existed as network modifiers. However, Cooney ${ }^{14)}$ and Waychunas ${ }^{15}$ considered that, for the $\mathrm{Na}_{2} \mathrm{O}-\mathrm{FeO}-\mathrm{SiO}_{2}$ and $\mathrm{K}_{2} \mathrm{O}-\mathrm{FeO}-$ $\mathrm{SiO}_{2}$ systems, ferrous ions were chiefly regarded as network formers, and only when divalent cations were absent, would a little ferrous ions fill the larger gaps caused by ferrous ions merging into the sites of silicate tetrahedrons. 
Consequently, there is no consensus on the structures of converter slag containing $\mathrm{Fe}^{2+}$ and $\mathrm{Fe}^{3+}$. In particular, researches on the structural evolution of forming slag in the early stage of basic oxygen steelmaking have not been paid attention yet. In this study, focusing on the evolution of slag composition during the early stage of basic oxygen steelmaking process, the structural transformation behaviors in the simplified slag system of $\mathrm{CaO}-\mathrm{SiO}_{2}-\mathrm{Fe}_{x} \mathrm{O}$ were investigated via Raman spectroscopy. The results will contribute to understand the macroscopic properties of converter slag and control metallurgical behavior.

\section{Experimental Procedures}

\subsection{Slag Composition Design}

In order to simulate componential transformation, referring to the composition of industrial converter slag during the initial smelting period and relevant literature, ${ }^{16,17)}$ five sets of samples with increasing basicity and decreasing total iron content were designed. The compositions of samples are as listed in Table 1 and its distribution is shown in Fig. 1. Although $\mathrm{FeO}$ initially substitutes total iron content, part of $\mathrm{FeO}$ will be oxidized to $\mathrm{Fe}_{2} \mathrm{O}_{3}$ by controlling the oxygen partial pressure. ${ }^{18,19)}$

For the converter slag in early smelting stage, the ratio of $\mathrm{Fe}^{3+}$ to $\mathrm{Fe}^{2+}$ in $\mathrm{Fe}_{x} \mathrm{O}$ content ranges from 0.20 to $0.45 .{ }^{18)}$ In order to make the value of $\mathrm{Fe}^{3+} / \mathrm{Fe}^{2+}$ within this range, a suitable oxygen partial pressure must be taken into account. Based on previous study, ${ }^{20)}$ it is found that when the value

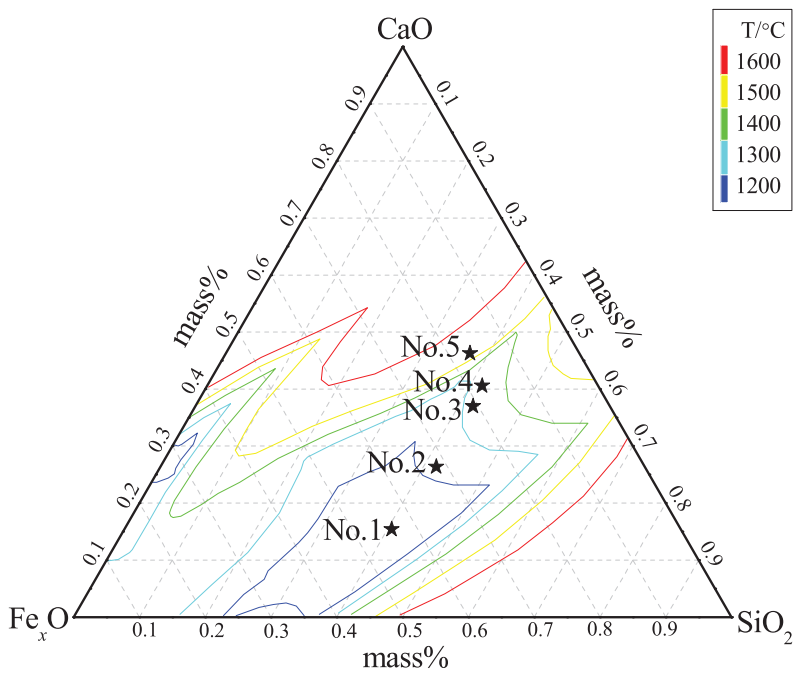

Fig. 1. Composition distribution of synthetic samples. (Online version in color.) of $\mathrm{Fe}^{3+} / \mathrm{Fe}^{2+}$ was between 0.13 and 0.16 at $1773 \mathrm{~K}$ in the $\mathrm{R}-\mathrm{Si}-\mathrm{Fe}-\mathrm{O}$ system $(\mathrm{R}=\mathrm{K}$ or $\mathrm{Na})$, oxygen partial pressure was approximately $10^{-10} \mathrm{~atm}$. The $\mathrm{Ca}-\mathrm{Si}-\mathrm{Fe}-\mathrm{O}$ system in this study is similar to the above system, so the oxygen partial pressure in our experiment can be designed in terms of $\mathrm{R}-\mathrm{Si}-\mathrm{Fe}-\mathrm{O}$ system.

The researches indicated that the iron redox state was as a function of pressure, temperature and bulk composition. ${ }^{13,20)}$ Under the same condition of other factors, the $\mathrm{Fe}^{3+}$ / $\mathrm{Fe}^{2+}$ ratio decreased with increasing ionic potential (Z/r) of non-framework cations and had positive correlation with oxygen partial pressure. ${ }^{13,18)}$ The $\mathrm{Z} / \mathrm{r}$ of $\mathrm{K}^{+}, \mathrm{Na}^{+}$and $\mathrm{Ca}^{2+}$ is $0.75,1.02,2.00$, respectively. Obviously, the $\mathrm{Z} / \mathrm{r}$ of $\mathrm{Ca}^{2+}$ is larger than that of $\mathrm{K}^{+}$and $\mathrm{Na}^{+}$, so the $\mathrm{Fe}^{3+} / \mathrm{Fe}^{2+}$ ratio of $\mathrm{Ca}-\mathrm{Si}-\mathrm{Fe}-\mathrm{O}$ melt is lower than that of $\mathrm{K}-\mathrm{Si}-\mathrm{Fe}-\mathrm{O}$ melt (namely, the $\mathrm{Fe}^{3+} / \mathrm{Fe}^{2+}$ ratio in the experimental sample is smaller than 0.13). Consequently, through slightly elevating the oxygen partial pressure, the $\mathrm{Fe}^{3+} / \mathrm{Fe}^{2+}$ ratio will increase and thereby will be controlled within the composition range of industrial slag. Therefore, the oxygen partial pressure during the preparation of sample is selected around $10^{-9} \mathrm{~atm}$.

\subsection{Samples Preparation}

The samples of $\mathrm{CaO}-\mathrm{SiO}_{2}-\mathrm{Fe}_{x} \mathrm{O}$ slag were prepared with the analytical reagents of $\mathrm{CaO}, \mathrm{SiO}_{2}$ and $\mathrm{Fe}_{2} \mathrm{C}_{2} \mathrm{O}_{4} \cdot 2 \mathrm{H}_{2} \mathrm{O}$. The $\mathrm{FeO}$ content was completely converted from the $\mathrm{Fe}_{2} \mathrm{C}_{2} \mathrm{O}_{4} \cdot 2 \mathrm{H}_{2} \mathrm{O}$ content. Before the experiment, $\mathrm{CaO}$ and $\mathrm{SiO}_{2}$ were calcined at $1273 \mathrm{~K}$ for $12 \mathrm{~h}$ to remove the traces of moisture and impurities. Then, the sample of $15 \mathrm{~g}$ was placed in platinum crucibles, which was suspended with Mo wire in the constant temperature zone of high temperature quenching furnace, as shown in Fig. 2. Thereafter, samples were heated up to a temperature of $1773 \mathrm{~K}$ and held at that temperature for $3 \mathrm{~h}$ to reach homogenization. ${ }^{21)}$ During the preparation of sample, a constant flow rate of argon ( 0.8 $\mathrm{L} \cdot \mathrm{min}^{-1}$, purity $>99.9999 \%$ ) was maintained. The oxygen partial pressure of gas was monitored by a $\mathrm{ZrO}_{2}-\mathrm{CaO}$ oxygen probe and was controlled about $10^{-9} \mathrm{~atm}$. After that, crucible fell into ice water within $0.5 \mathrm{~s}$ by opening removable cap and loosening Mo wire.

\subsection{Composition and Structure Detection}

The compositions of quenched samples were analyzed by $\mathrm{X}$-ray fluorescence spectrometer (S4 explorer, Germany). Yet, the iron ions in $\mathrm{Fe}_{x} \mathrm{O}$ were not specified as $\mathrm{Fe}^{2+}$ or $\mathrm{Fe}^{3+}$, so the values of $\mathrm{Fe}^{2+} / \sum \mathrm{Fe}$ and $\mathrm{Fe}^{3+} / \sum \mathrm{Fe}$ were ascertained by the direct analysis of $\mathrm{Fe}^{2+}$ using the $\mathrm{K}_{2} \mathrm{Cr}_{2} \mathrm{O}_{7}$ titration method (JIS M 8212:2005). Besides, X-ray diffraction (XRD) patterns over the range of $2 \theta=0-90^{\circ}$ were

Table 1. Compositions of synthetic samples/mass $\%$.

\begin{tabular}{|c|c|c|c|c|c|c|c|c|}
\hline \multirow{2}{*}{ Sample } & \multicolumn{4}{|c|}{ Designed composition/Analyzed composition } & \multirow{2}{*}{$\mathrm{Fe}_{2} \mathrm{O}_{3}$} & \multirow{2}{*}{$\mathrm{Fe}^{2+} / \sum \mathrm{Fe}$} & \multirow{2}{*}{$\mathrm{Fe}^{3+} / \sum \mathrm{Fe}$} & \multirow{2}{*}{ Total iron } \\
\hline & Basicity & $\mathrm{CaO}$ & $\mathrm{SiO}_{2}$ & $\mathrm{FeO}$ & & & & \\
\hline No. 1 & $0.33 / 0.38$ & $15.00 / 15.41$ & $40.00 / 40.66$ & $45.00 / 25.57$ & 18.40 & 0.65 & 0.35 & 32.77 \\
\hline No. 2 & $0.65 / 0.63$ & $25.00 / 26.37$ & $40.00 / 41.95$ & $35.00 / 20.02$ & 12.02 & 0.69 & 0.31 & 23.98 \\
\hline No. 3 & $0.85 / 0.87$ & $35.00 / 36.94$ & $40.00 / 42.24$ & $25.00 / 13.71$ & 7.11 & 0.72 & 0.28 & 15.64 \\
\hline No. 4 & $1.00 / 0.97$ & $40.00 / 40.56$ & $40.00 / 41.83$ & $20.00 / 11.99$ & 5.62 & 0.74 & 0.26 & 13.26 \\
\hline No. 5 & $1.25 / 1.25$ & $45.00 / 46.27$ & $35.00 / 37.11$ & $20.00 / 11.51$ & 5.11 & 0.75 & 0.25 & 12.53 \\
\hline
\end{tabular}


performed by X'pert PRO diffractometer (PANalytiical, Holland), which determined whether the amorphous solid state was achieved.

The quenched slags were optically analyzed using Raman spectroscopy. The Raman spectra were recorded by a multichannel modular triple Raman system (JY-HR800, France) with the excitation wave-length of $488 \mathrm{~nm}$ and a $1 \mathrm{~mW}$ semiconductor laser as light source. The measured range of frequency band was from 100 to $4000 \mathrm{~cm}^{-1}$ and the resolution of spectrum was $0.65 \mathrm{~cm}^{-1}$.

\subsection{Data Processing of Raman Spectra}

After the measurement of Raman spectroscopy, raw curves were not smooth due to the presence of noise signal, and the ends of curves were not on the same horizontal line due to the fluorescence effect of Raman test. Therefore, curves should be firstly smoothed to remove the influence of noise on the accuracy of spectra, and then the baselines of curves were subtracted. The above treatment procedure is shown in Figs. 3(a)-3(c).

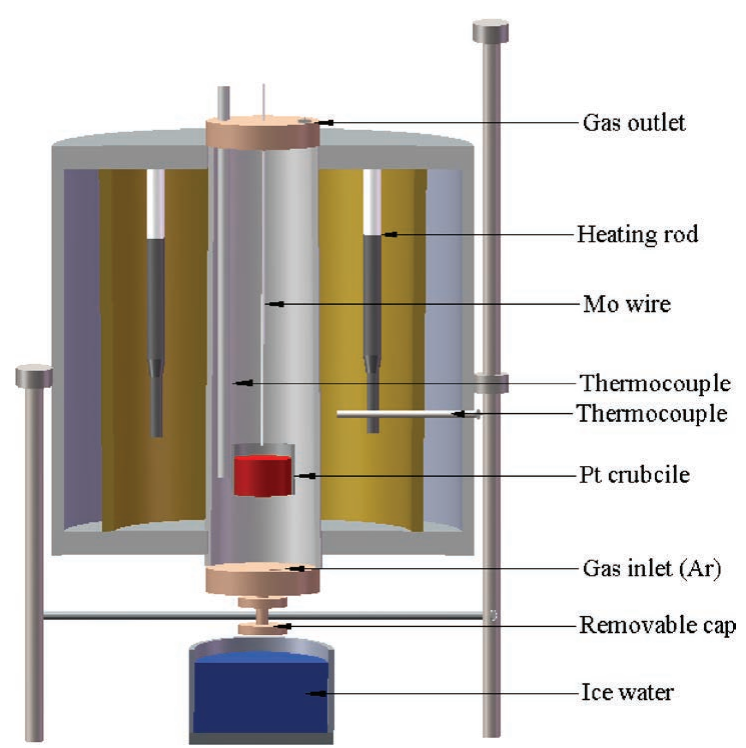

Fig. 2. Schematic representation of high temperature quenching furnace. (Online version in color.)

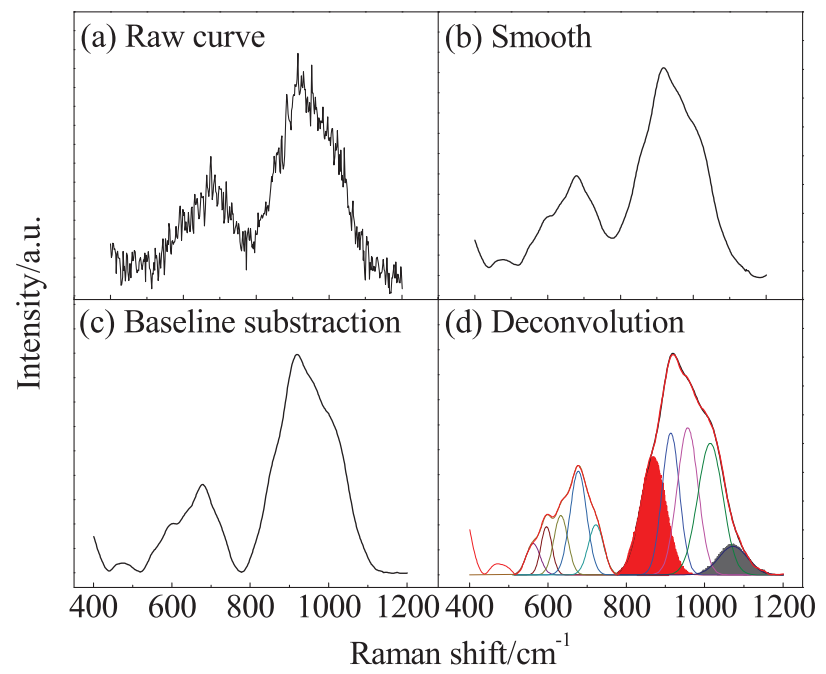

Fig. 3. Data processing of Raman spectroscopy. (Online version in color.)
The processed curves were fitted using the GaussingDeconvolution function in the Origin 9.0 software. In our fits, band position, width and intensity were treated as independent variables. The individual deconvoluted peaks were fitted consecutively until the minimum correlation coefficient $\mathrm{R}^{2}>0.99$, which could be considered that the fitting result is comparatively accurate. What's more, the characteristic peaks obtained from the Gaussian-Deconvolution result could be used to calculate the corresponding area by the integral method, as shown in Fig. 3(d). The ratio of integrated area of a characteristic peak to the sum of all the characteristic peaks could give the fraction of a specific structural unit in the molten slag. Currently, this method has been widely used by scholars in the deconvolution of Raman spectroscopy. ${ }^{22-25)}$

\section{Results and Discussion}

\subsection{Sample Phase and Composition}

The analyzed compositions of quenched samples are also listed in Table 1. It shows that the compositions of $\mathrm{SiO}_{2}$ and $\mathrm{CaO}$ slightly deviate from the designed values. It also shows that bivalent iron and trivalent iron co-exist in slag samples. With increasing order of samples from No. 1 to No. 5, the mole ratio of $\mathrm{Fe}^{3+} / \sum \mathrm{Fe}$ decreases from 0.35 to 0.26 . The reason for decreasing $\mathrm{Fe}^{3+} / \sum \mathrm{Fe}$ is possibly related to the varying basicity and total iron content.

There have been many studies on redox state for iron ions, and studies showed that increasing basicity could increase the value of $\mathrm{Fe}^{3+} / \mathrm{Fe}^{2+} \cdot{ }^{19,21)}$ These studies discussed the effect of basicity on iron redox state on the condition of fixing total iron content. However, in our experimental slags, both basicity and total iron content changes. Basicity increases from 0.38 to 1.25 and $\mathrm{FeO}$ content simultaneously decreases from 45 to 20 mass $\%$. Mysen et al. ${ }^{18,26-28)}$ reported that $\mathrm{Fe}^{3+} / \mathrm{Fe}^{2+}$ decreased with decreasing total iron content regardless of the form in which iron was added. Therefore, we thought that the decreasing addition of total iron is the main reason for the decreasing $\mathrm{Fe}^{3+} / \sum \mathrm{Fe}$ ratio. Although $\mathrm{Fe}^{3+} / \sum \mathrm{Fe}$ ratio has a little change, its value is still within the range of designed composition. Hence, the composition evolution of converter slags during the early stage can be represented by synthetic samples.

The phase analyses of quenched samples are shown in Fig. 4. All the XRD profiles only showed a broad peak around the diffraction angle $2 \theta$ of $30^{\circ}$. This is so-called hola pattern confirming that samples are amorphous. ${ }^{18)}$ Hence, these glassy samples could be considered to maintain the high temperature state of melt structure, and thereby substituted the high-temperature molten slag for analyzing the microscopic structures. ${ }^{29,30)}$

\subsection{Raman Spectra}

Figure 5 presents the Raman spectra of all the investigated slags and the spectra of five slags exhibit similar spectral features. There is a weak peak at low-frequency region (LF: $400-500 \mathrm{~cm}^{-1}$ ) and two broad envelope peaks at intermediate-frequency region (MF: $500-780 \mathrm{~cm}^{-1}$ ) and high-frequency region (HF: 780-1 $150 \mathrm{~cm}^{-1}$ ), respectively.

In the silicate glasses, the MF envelope peak is traditionally interpreted as the convolution of the delocalized modes 


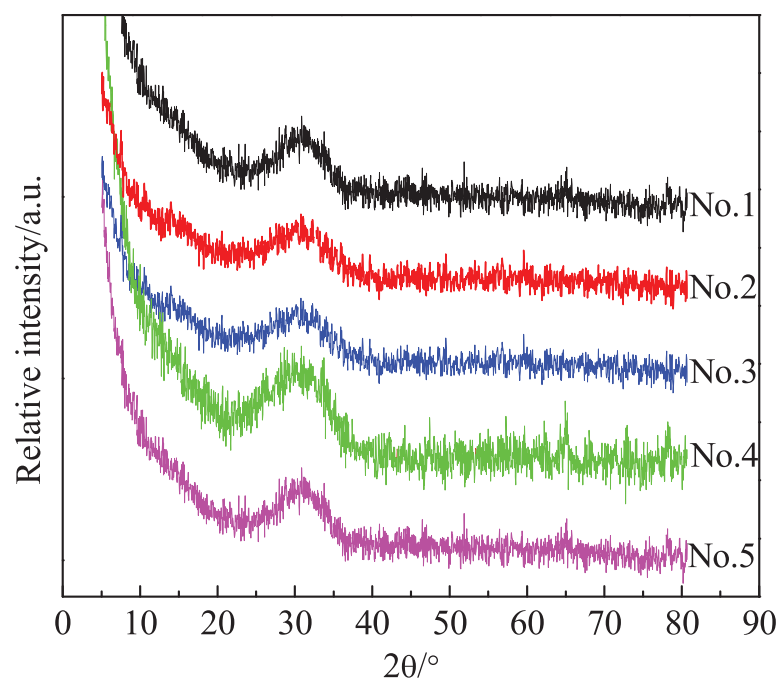

Fig. 4. X-ray diffraction pattern of the samples quenching at 1773 $\mathrm{K}$. (Online version in color.)

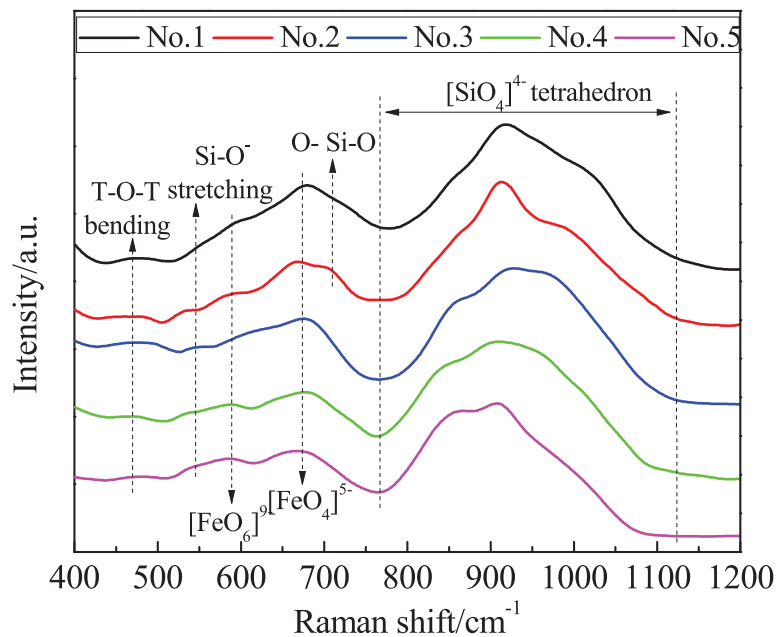

Fig. 5. Raman spectra of quenched samples. (Online version in color.)

of vibration related to $\mathrm{Si}-\mathrm{O}$ stretching and the breathing modes of four- and three-membered ring structures of $\left[\mathrm{SiO}_{4}\right]^{4-}$ tetrahedrons. ${ }^{31-34)}$ The HF envelope peak is typical of NBO-bearing slags and is the most sensitive to compositions. It has been interpreted as the convolution of bands related to symmetric $\mathrm{Si}-\mathrm{O}$ stretching vibrations of units with variable numbers of bridging oxygen $\left(\mathrm{Q}^{n}: n\right.$ being the number of BO). ${ }^{31,32,35,36)}$ In addition, some studies revealed that the vibration involving $\mathrm{Fe}^{3+}$ could exist in these regions. Based on Mössbauer spectra, Mysen et al. ${ }^{37)}$ suggested that $\mathrm{Fe}^{3+}$ were four-fold and six-fold coordinated cations and could form $\left[\mathrm{FeO}_{4}\right]^{5-}$ tetrahedron and $\left[\mathrm{FeO}_{6}\right]^{9-}$ octahedron in molten slag. Lucazeau et al. ${ }^{38)}$ and Iordanova et al. ${ }^{39)}$ showed that the bands at $\sim 550$ and $\sim 670 \mathrm{~cm}^{-1}$ were assigned to the $\mathrm{Fe}-\mathrm{O}$ stretching vibration of $\left[\mathrm{FeO}_{6}\right]^{9-}$ octahedron and $\left[\mathrm{FeO}_{4}\right]^{5-}$ tetrahedron, respectively. Genova et al. ${ }^{40,41)}$ revealed that $\mathrm{Fe}-\mathrm{O}$ vibration appeared in the $\mathrm{HF}$ envelope peak and named the band at $\sim 970 \mathrm{~cm}^{-1}$ as " $\mathrm{Fe}^{3+}$ band". Muro et al. ${ }^{42)}$ reported that the band at $\sim 980 \mathrm{~cm}^{-1}$ was attributed to anti-symmetric coupled mode of $\mathrm{FeO}_{4}-\mathrm{SiO}_{4}$ tetrahedrons.

In the present studied spectra, the MF region exhibits one broad band composed of four different peaks located at $\sim 545, \sim 590, \sim 670$ and $\sim 710 \mathrm{~cm}^{-1}$, respectively. As the chemical composition of slags varies, the intensity of $\mathrm{MF}$ envelope peak gradually decreases, coinciding with the decreasing tendency of $\mathrm{Fe}_{2} \mathrm{O}_{3}$ from 18.40 to 5.11 mass\%. Accordingly, the MF envelope peak is speculated to be associated with the $\mathrm{Fe}-\mathrm{O}$ vibration aside from being related to the $\mathrm{Si}-\mathrm{O}$ vibration aforementioned. According to the above investigations, ${ }^{37-39,43)}$ the bands at $\sim 590$ and $\sim 670 \mathrm{~cm}^{-1}$ of measured spectra can represent the $\left[\mathrm{FeO}_{4}\right]^{5-}$ tetrahedron and $\left[\mathrm{FeO}_{6}\right]^{9-}$ octahedron, respectively. The vibrational bands of $\mathrm{Fe}^{3+}$ in the MF region also have been verified in our previous studies by comparing the Raman spectra of $\mathrm{Fe}_{2} \mathrm{O}_{3}$-bearing glass with $\mathrm{Fe}_{2} \mathrm{O}_{3}$-free glass. ${ }^{44,45)}$ Meanwhile, the peak width of $\left[\mathrm{FeO}_{4}\right]^{5-}$ tetrahedron and $\left[\mathrm{FeO}_{6}\right]^{9-}$ octahedron has an obvious change, indicating that the structural behavior of $\mathrm{Fe}^{3+}$ is apt to be affected by slag composition. The detailed reason will be discussed in the following section 3.4.

Furthermore, the MF envelope peak is also affected by basicity. With increasing basicity from 0.38 to 1.25 , the peak intensity at $\sim 545 \mathrm{~cm}^{-1}$ increases and the peak at $\sim 710 \mathrm{~cm}^{-1}$ gradually disappears. The possible reason is that $\mathrm{O}^{2-}$ ions dissociated from $\mathrm{CaO}$ can cut off the $\mathrm{BO}$ bond of $\left[\mathrm{SiO}_{4}\right]^{4-}$ tetrahedron, resulting in the increasing number of non-bridging oxygen (NBO). It is manifested in the gradual intense vibration of NBO bond and the gradual weakened vibration of $\mathrm{BO}$ bond. According to the previous researches, ${ }^{31-34,46)}$ the peaks at $\sim 545$ and $\sim 710 \mathrm{~cm}^{-1}$ are assigned to the $\mathrm{Si}-\mathrm{O}^{-}$stretching vibration and the $\mathrm{O}-\mathrm{Si}-\mathrm{O}$ vibration of four- or three-membered $\left[\mathrm{SiO}_{4}\right]^{4-}$ ring $\left(\mathrm{Q}^{2}\right)$, respectively. These assignments of Raman bands are listed in Table 2.

Concerning the HF region, the spectra show that one broad asymmetric band composed by three different peaks: a main peak located at $\sim 855 \mathrm{~cm}^{-1}$, a shoulder on the left side at $\sim 910 \mathrm{~cm}^{-1}$, and a shoulder on the right side at $\sim 1000$ $\mathrm{cm}^{-1}$. Along the order of designed samples, the width of HF envelope peak narrows markedly, and the left shoulder becomes progressively evident, but the right shoulder wears off and shifts toward lower frequency. The possible reason for the variation of shoulder is that inter-tetrahedral vibration mode of polymerized species has altered, which maybe $\left[\mathrm{SiO}_{4}\right]^{4-}$ tetrahedron or $\left[\mathrm{FeO}_{4}\right]^{4-}$ tetrahedron. ${ }^{42)}$

In addition, the weak band at $470 \mathrm{~cm}^{-1}$ is attributed to the bending vibration involving $\mathrm{T}-\mathrm{O}-\mathrm{T}$ bridging oxygen relative to almost stationary 4 -fold coordinated cations in the $\mathrm{TO}_{4}$ units, where $\mathrm{T}$ refers to fourfold cations $\left(\mathrm{Si}^{4+}\right.$, $\left.\mathrm{Fe}^{3+}\right) .{ }^{47-49)}$ With the increasing order of samples, the peak intensity of $\mathrm{T}-\mathrm{O}-\mathrm{T}$ bond becomes less pronounced.

\subsection{Structure and Polymerization of Silicon}

In order to clarify the existence of structural units, the Raman spectra between 400 and $1200 \mathrm{~cm}^{-1}$ should be treated by the Gaussian-Deconvolution function. The curvefitting method has been given in section 2.4. During curvefitting, if it is assumed that the HF region is consisted of $\left[\mathrm{SiO}_{4}\right]^{4-}$ tetrahedron alone, the line parameters of Raman shift located at 780-1 $200 \mathrm{~cm}^{-1}$ will be assigned to $\sim 850$, $\sim 920, \sim 970$ and $\sim 1050 \mathrm{~cm}^{-1}$. $^{31,32)}$ After the deconvolution, the non-bridging oxygen number $(\mathrm{NBO} / \mathrm{T})$ calculated by Raman spectra is slightly higher than the nominal value of $\mathrm{NBO} / \mathrm{T}$, deviating from the truth (the methods of obtaining 
ISIJ International, Vol. 60 (2020), No. 2

Table 2. Assignments of Raman bands in spectra of $\mathrm{CaO}-\mathrm{SiO}_{2}-\mathrm{Fe}_{x} \mathrm{O}$ slag system.

\begin{tabular}{ccc}
\hline Raman shift $/ \mathrm{cm}^{-1}$ & Raman assignment & Reference \\
\hline 460 & Bending vibrations of T-O-T, $\mathrm{T}=\mathrm{Si}, \mathrm{Fe}$ & $47-49)$ \\
$532-548$ & Stretching vibrations of $\mathrm{Si}-\mathrm{O}^{-}$ & $31-34)$ \\
592 & Symmetric stretching vibrations of $\left[\mathrm{FeO}_{6}\right]^{9-}$ & $37-39,43)$ \\
$654-675$ & Symmetric stretching vibrations of $\left[\mathrm{FeO}_{4}\right]^{4-}$ & $37-39,43)$ \\
$705-729$ & Vibration of O-Si-O in four- or three- membered $\left[\mathrm{SiO}_{4}\right]^{4-}$ rings $\left(\mathrm{Q}^{2}\right)$ & $31-34,46)$ \\
$850-880$ & Symmetric stretching vibrations of $\left[\mathrm{SiO}_{4}\right]^{4-}$ with $\mathrm{NBO} / \mathrm{Si}=4\left(\mathrm{Q}^{0}\right)$ & $31,32,35,36)$ \\
$900-920$ & Symmetric stretching vibrations of $\left[\mathrm{SiO}_{4}\right]^{4-}$ with $\mathrm{NBO} / \mathrm{Si}=3\left(\mathrm{Q}^{1}\right)$ & \\
$950-980$ & Symmetric stretching vibrations of $\left[\mathrm{SiO}_{4}\right]^{4-}$ with $\mathrm{NBO} / \mathrm{Si}=2\left(\mathrm{Q}^{2}\right)$ & \\
$970-1000$ & Anti-symmetric stretching vibrations of $\mathrm{Fe}_{-} \mathrm{O}-\mathrm{Si}$ with $\mathrm{NBO} / \mathrm{T}=1\left(\mathrm{Q}^{3}\right)$ & \\
$1050-1100$ & Symmetric stretching vibrations of $\left[\mathrm{SiO}_{4}\right]^{4-}$ with $\mathrm{NBO} / \mathrm{Si}=1\left(\mathrm{Q}^{3}\right)$ & \\
\hline
\end{tabular}

$\mathrm{NBO} / \mathrm{T}$ are expressed in the following part). Consequently, the hypothesis of line parameters is only not very comprehensive.

In order to find the more accurate line parameters, plenty of literature is further analyzed. Investigations showed that the $\mathrm{HF}$ region was the overlapping zone of $\mathrm{Fe}-\mathrm{O}$ and $\mathrm{Si}-\mathrm{O}$ vibration, and was difficult to distinguish the vibrational location of $\mathrm{Fe}^{3+}$ from the $\mathrm{Si}-\mathrm{O}$ vibration of $\left[\mathrm{SiO}_{4}\right]^{4-}$ tetrahedron. $^{35,36,40-42)}$ Nonetheless, some studies ${ }^{42,43,46)}$ showed that the band at $\sim 1000 \mathrm{~cm}^{-1}$ was the vibration of $\mathrm{Si}-\mathrm{O}-\mathrm{Fe}$ bond. Consequently, during the curve-fitting process, the extra line parameters can be added at $\sim 1000 \mathrm{~cm}^{-1}$, which represents the $\mathrm{Si}-\mathrm{O}-\mathrm{Fe}$ bond. All the assignments of Raman bands listed in Table 2 provide a straightforward reference for deconvolution. Moreover, all the Raman spectra were deconvoluted with $\mathrm{R}^{2}>0.999$, as shown in Fig. 6. The relative area fractions and Raman shifts of characteristic peaks obtained from deconvolution are shown in Fig. 7 and Table 3, respectively.

The weak changes in the intensity of Raman bands along with the weak shifts in band position can both reflect minor changes undergone by silicate bonds. ${ }^{46)}$ As can be seen from Table 3, all the Raman shifts of $\mathrm{Q}^{n}$ move towards lower frequency, indicating in a decline in strength of $\mathrm{Si}-\mathrm{O}$ bond. The reason for shifting is that more and more NBO bonds are generated, causing the increase in low-polymerized silica tetrahedrons.

In addition, it is known from the deconvolution result that the Raman shift of $\mathrm{Si}-\mathrm{O}-\mathrm{Fe}$ bond locates at $\sim 1010 \mathrm{~cm}^{-1}$. We speculate that there is a possibility that the $\mathrm{Si}-\mathrm{O}-\mathrm{Fe}$ bond is formed due to $\mathrm{Si}^{4+}$ of $\mathrm{Q}^{3}$ units replaced by $\mathrm{Fe}^{4+}$. Judging from the force constants, the force constant of $\mathrm{Fe}-\mathrm{O}$ bond (86.3) is smaller than that of $\mathrm{Si}-\mathrm{O}$ bond (225.6), so the bond length of $\mathrm{Fe}-\mathrm{O}$ is longer than that of $\mathrm{Si}-\mathrm{O}{ }^{50)}$ When $\mathrm{Si}-\mathrm{O}-\mathrm{Si}$ bond is substituted by $\mathrm{Si}-\mathrm{O}-\mathrm{Fe}$ bond, the band of $\mathrm{Q}^{3}$ will shift towards low frequency. ${ }^{51)} \mathrm{It}$ is known from the above results that the band of $\mathrm{Q}^{3}$ containing $\mathrm{Si}-\mathrm{O}-\mathrm{Fe}$ indeed locates at lower Raman shift, indicating that our speculation is relatively reasonable.

Through further calculating NBO/T, the DOP of molten slag can be quantitatively described. Equation (1) is the calculation formulas for the experimental $\mathrm{NBO} / \mathrm{T}(\mathrm{NBO} /$ $\mathrm{T}_{\text {exp }}$ ) combining with deconvolution result, and Eq. (2) is the calculation formulas for the nominal $\mathrm{NBO} / \mathrm{T}\left(\mathrm{NBO} / \mathrm{T}_{\mathrm{Si}}\right.$ and

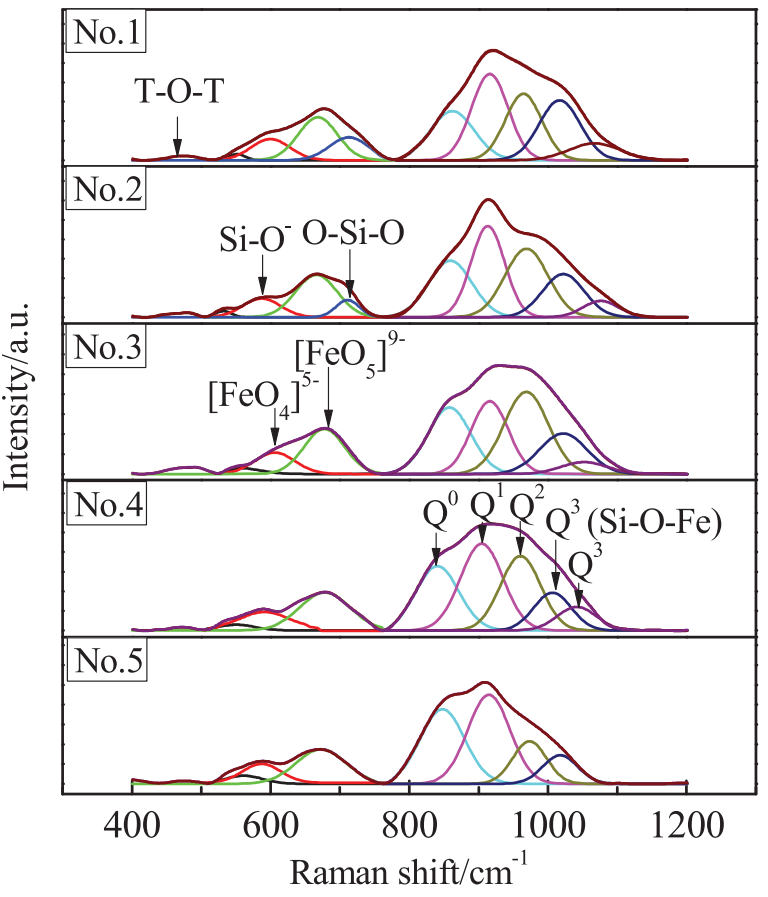

Fig. 6. Deconvolution of Raman spectra over a wide wavenumber of 400-1 $200 \mathrm{~cm}^{-1}$. (Online version in color.)

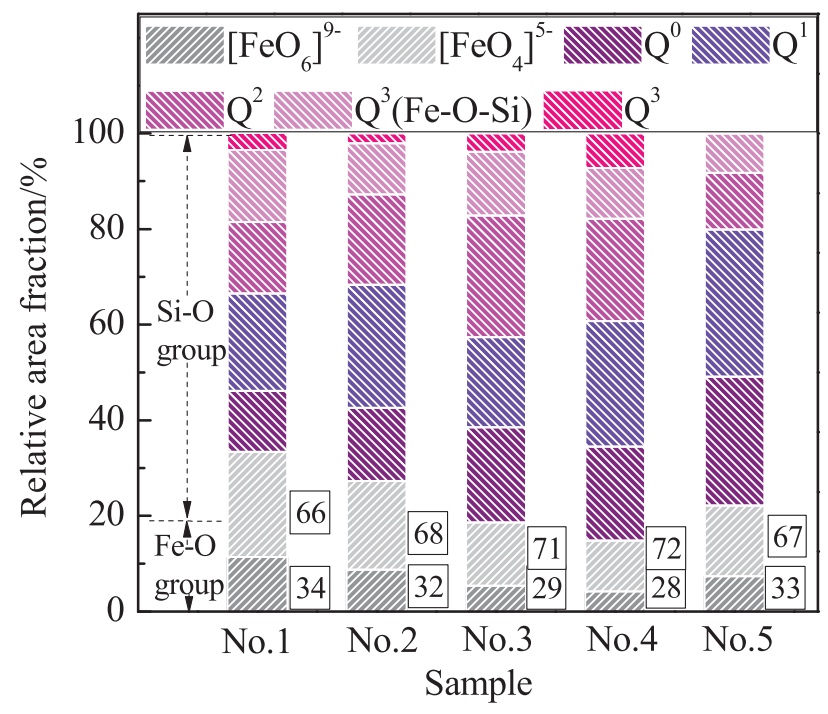

Fig. 7. Relative area fraction of structural units. (Online version in color.) 
ISIJ International, Vol. 60 (2020), No. 2

Table 3. Raman shifts of units in deconvoluted spectra.

\begin{tabular}{cccccccccc}
\hline \multirow{2}{*}{ Sample } & \multicolumn{8}{c}{ Raman shift/cm } \\
\cline { 2 - 10 } & $\mathrm{Si}-\mathrm{O}^{-}$ & {$\left[\mathrm{FeO}_{4}\right]^{5-}$} & {$\left[\mathrm{FeO}_{6}\right]^{9-}$} & $\mathrm{O}-\mathrm{Si}-\mathrm{O}$ & $\mathrm{Q}^{0}$ & $\mathrm{Q}^{1}$ & $\mathrm{Q}^{2}$ & $\mathrm{Q}^{3}(\mathrm{Si}-\mathrm{O}-\mathrm{Fe})$ & $\mathrm{Q}^{3}$ \\
\hline No.1 & 551 & 586 & 669 & 771 & 862 & 914 & 964 & 1018 & 1069 \\
No.2 & 543 & 606 & 664 & 709 & 859 & 911 & 966 & 1022 & 1076 \\
No.3 & 560 & 606 & 678 & $/$ & 858 & 914 & 958 & 1021 & 1054 \\
No.4 & 552 & 590 & 678 & $/$ & 840 & 903 & 960 & 1007 & 1041 \\
No.5 & 561 & 587 & 672 & $/$ & 842 & 913 & 972 & 1016 & $/$ \\
\hline
\end{tabular}

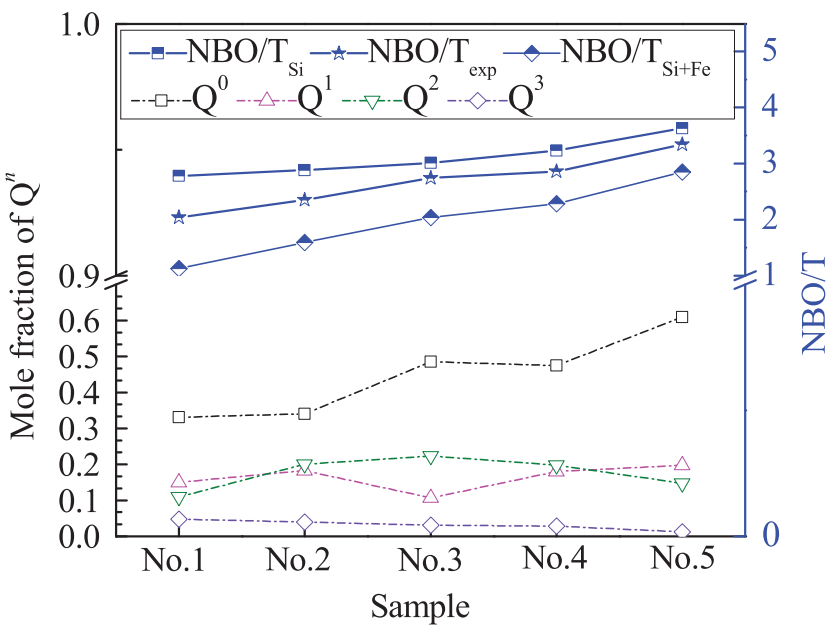

Fig. 8. Mole fraction of $\mathrm{Q}^{n}$ and $\mathrm{NBO} / \mathrm{T}$. (Online version in color.)

$\mathrm{NBO} / \mathrm{T}_{\mathrm{Si}+\mathrm{Fe}}$ ) combining with composition of Table $1 .^{32,52)}$ The calculation results are shown in Fig. 8.

$$
\begin{gathered}
\mathrm{NBO} / \mathrm{T}=\sum X_{i}(4-i) \cdots \\
\mathrm{NBO} / \mathrm{T}=\left(2 x_{\mathrm{O}}-4 x_{\mathrm{T}}\right) / x_{\mathrm{T}}
\end{gathered}
$$

Where, $X_{i}$ is the mole fraction of each tetrahedron in Eq. (1); $x_{\mathrm{O}}$ is the mole fraction of oxygen atom and $x_{\mathrm{T}}$ is the mole fraction of tetrahedron in Eq. (2).

In Fig. 8, with the increasing order of samples, the mole fraction of $\mathrm{Q}^{0}$ increases gradually from 0.33 to 0.61 and the mole fraction of $\mathrm{Q}^{3}$ decreases from 0.05 to 0.01 . Yet, the mole fraction of $\mathrm{Q}^{1}$ and $\mathrm{Q}^{2}$ fluctuates near 0.17 and 0.19 , respectively. Obviously, $\mathrm{O}^{2-}$ dissociated from $\mathrm{CaO}$ and $\mathrm{FeO}$ can cut off $\mathrm{Si}-\mathrm{O}-\mathrm{Si}$ bond, causing that $\left[\mathrm{SiO}_{4}\right]^{4-}$ units are dissociated. ${ }^{41)}$ The depolymerization process is represented by the Eq. $(3),{ }^{12,53)}$ which coincides with the depolymerization mechanism proposed by Mysen et al. ${ }^{12)}$ In addition, the increasing $\mathrm{NBO} / \mathrm{T}$ with increasing basicity also indicates the depolymerization of molten slag. Therefore, during the primary steelmaking process, the DOP of molten slag gradually decreases.

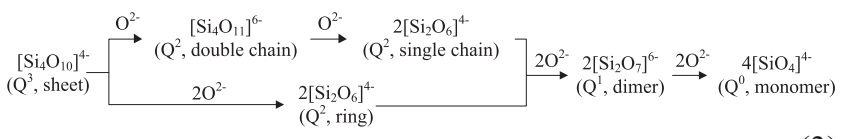

\subsection{Structural Behavior of $\mathbf{F e}^{3+}$}

Figure 7 shows the relative area fractions of the ferrite structures with fourfold and sixfold coordination. As basic- ity increases from 0.38 to 0.97 and total iron decreases from 32.77 to 13.26 mass \% simultaneously (being regarded as the stage of low basicity and high iron), the relative area of $\left[\mathrm{FeO}_{4}\right]^{5-}$ tetrahedron (network former) increases continuously, whereas the relative area of $\left[\mathrm{FeO}_{6}\right]^{9-}$ tetrahedron (network modifier) decreases steadily. In this stage, the majority of $\mathrm{O}^{2-}$ ions enter $\left[\mathrm{SiO}_{4}\right]^{4-}$ tetrahedron, playing the role of cutting off $\mathrm{Si}-\mathrm{O}-\mathrm{Si}$ bonds. Only a small part of $\mathrm{O}^{2-}$ ions surround around $\mathrm{Fe}^{3+}$. With the increasing $\mathrm{O}^{2-}$ dissociated from $\mathrm{CaO}$, the ability of forming tetrahedron by $\mathrm{Fe}^{3+}$ enhances gradually, which promoted the increasing ratio of $\left[\mathrm{FeO}_{4}\right]^{5-} /\left[\mathrm{FeO}_{6}\right]^{9-}$. Although the net-like structures formed by $\mathrm{Fe}^{3+}$ increase, the depolymerization of $\left[\mathrm{SiO}_{4}\right]^{4-}$ tetrahedron is the main process. As a result, the DOP of molten slag in this stage continuously decreases. Similar results were found in the Rüssel's research ${ }^{19)}$ that larger basicity concentrations led to a better stabilization of $\left[\mathrm{FeO}_{4}\right]^{5-}$ tetrahedron.

However, with further increasing basicity from 0.97 to 1.25 and decreasing total iron content from 13.26 to 12.53 mass \% (being regarded as the stage of high basicity and low iron), the relative ratio of units formed by $\mathrm{Fe}^{3+}$ has great changes. It is observed that the relative area of $\left[\mathrm{FeO}_{4}\right]^{5-}$ tetrahedron decreases significantly and the relative area of $\left[\mathrm{FeO}_{6}\right]^{9-}$ octahedron increases obviously. The possible reason for the decreasing $\left[\mathrm{FeO}_{4}\right]^{5-} /\left[\mathrm{FeO}_{6}\right]^{9-}$ ratio can be explained as follows. When basicity is $0.97, \mathrm{NBO} / \mathrm{T}_{\exp }$ is 2.87 , indicating that the DOP of molten slag is in the lower state. At this moment, $\left[\mathrm{SiO}_{4}\right]^{4-}$ units can only accommodate the minority of $\mathrm{O}^{2-}$, forming a circumstance that a small quantity of $\mathrm{Fe}^{3+}$ cations are encompassed by surplus $\mathrm{O}^{2-}$. In order to maintain the balance of melt, $\mathrm{O}^{2-}$ will react with $\left[\mathrm{FeO}_{4}\right]^{5-}$ tetrahedron to form $\left[\mathrm{FeO}_{6}\right]^{9-}$ octahedron through Eq. (4). It results in the decreasing $\left[\mathrm{FeO}_{4}\right]^{5-} /\left[\mathrm{FeO}_{6}\right]^{9-}$ ratio and favors the depolymerization of molten slag. Figure 9 describes the structural behavior of $\mathrm{Fe}^{3+}$ in silicate melt. Similar result has been reported by Bowker et al. ${ }^{54)}$ who found that $\mathrm{Fe}^{3+}$ behaved primarily as a network modifier in very-low iron glasses. Vadász et al. ${ }^{55)}$ also considered that the coordination of central ferric atom might be changed from tetrahedron to octahedron depending on the surplus of free oxygen ions in the complex $\mathrm{Fe}^{3+}$ anions.

$$
\left[\mathrm{FeO}_{4}\right]^{5-}+2 \mathrm{O}^{2-}=\left[\mathrm{FeO}_{6}\right]^{9-}
$$

Based on the above results, $\mathrm{Fe}^{3+}$ coordinated with four oxygen atoms forms a $\left[\mathrm{FeO}_{4}\right]^{5-}$ tetrahedron, which acts as network former, and $\mathrm{Fe}^{3+}$ coordinated with six oxygen atoms form a $\left[\mathrm{FeO}_{6}\right]^{9-}$ octahedron which acts as network modifier. However, the vibration related to $\mathrm{Fe}^{2+}$ is 


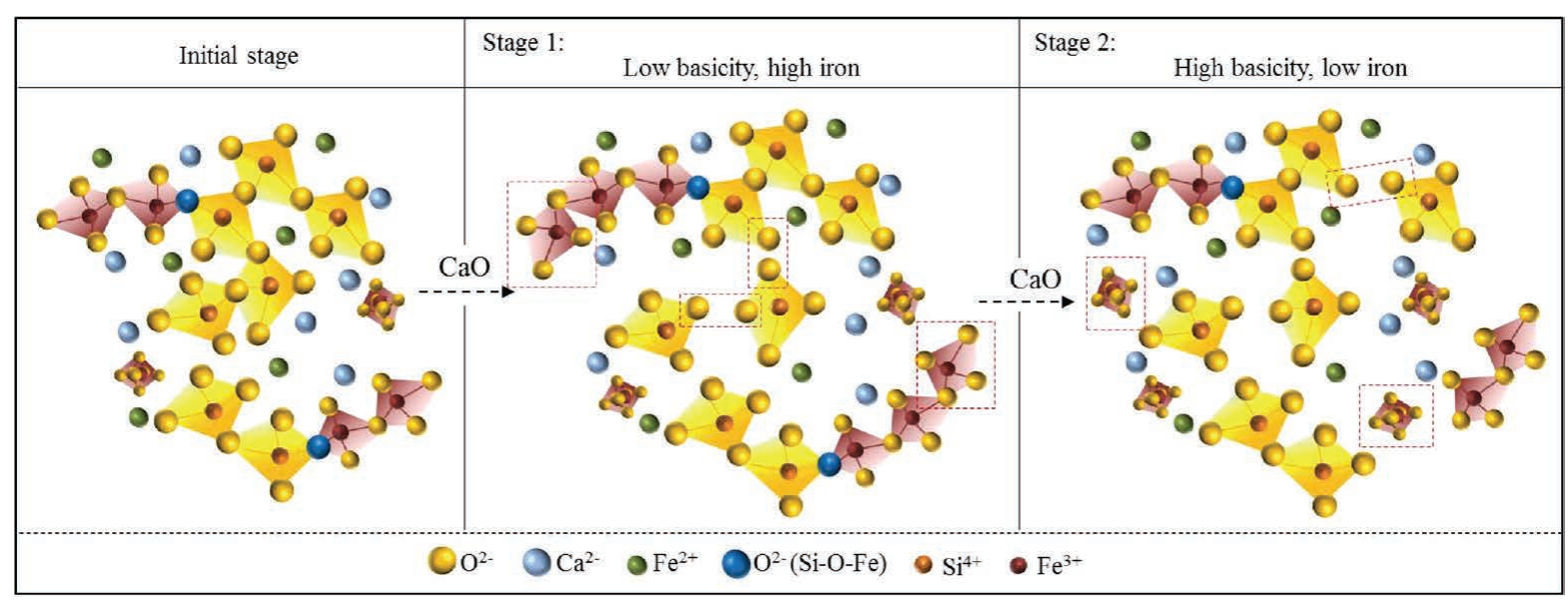

Fig. 9. Structural evolution of $\mathrm{CaO}-\mathrm{SiO}_{2}-\mathrm{Fe}_{x} \mathrm{O}$ molten slag. (Online version in color.)

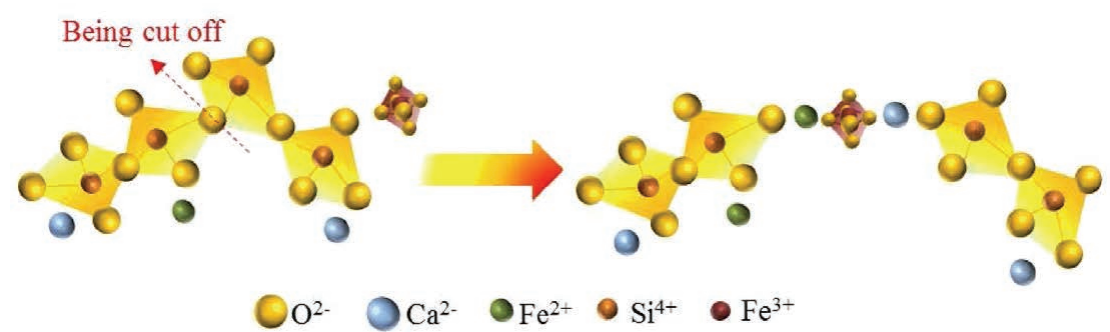

Fig. 10. Sketch of modifying silicate structure by $\left[\mathrm{FeO}_{6}\right]^{9-}$ octahedron. (Online version in color.)

not detected in Raman spectra, so $\mathrm{Fe}^{2+}$ is considered as non-framework cation, which acts as charge compensation in the molten slag.

The experimental results show that, $\mathrm{Fe}^{3+}$ in the silicate melt is ascertained to have a similar role of $\mathrm{Al}^{3+}$, which is the same as the Wang's research. ${ }^{43)}$ Referring to the role of $\left[\mathrm{AlO}_{6}\right]^{9-}$ octahedron, $\left[\mathrm{FeO}_{6}\right]^{9-}$ octahedron can modify the chain-like silicate tetrahedron, as shown in Fig. 10. When the $\mathrm{BO}$ bonds of $\left[\mathrm{SiO}_{4}\right]^{4-}$ tetrahedrons are cut off, $\mathrm{NBO}$ bonds formed can be combined with $\left[\mathrm{FeO}_{6}\right]^{9-}$ octahedrons by linking $\mathrm{Ca}^{2+}$ or $\mathrm{Fe}^{2+}$ cations.

Apart from the above structural units, another type of $\mathrm{Fe}^{3+}$ may exist in the molten slag. In Fig. 7, comparing the experimental $\mathrm{NBO} / \mathrm{T}$ with the nominal $\mathrm{NBO} / \mathrm{T}, \mathrm{NBO} / \mathrm{T}_{\exp }$ is between the $\mathrm{NBO} / \mathrm{T}_{\mathrm{Si}+\mathrm{Fe}}$ and $\mathrm{NBO} / \mathrm{T}_{\mathrm{Si}}$, namely $\mathrm{NBO} /$ $\mathrm{T}_{\mathrm{Si}+\mathrm{Fe}}<\mathrm{NBO} / \mathrm{T}_{\exp }<\mathrm{NBO} / \mathrm{T}_{\mathrm{Si}}$. It indicates that all the $\mathrm{Si}^{4+}$ cations form tetrahedrons taking precedence over $\mathrm{Fe}^{3+}$, but the $\mathrm{Fe}^{3+}$ cations do not form tetrahedrons completely. Investigation into $\mathrm{NBO} / \mathrm{T}_{\exp }$ shows that the $\mathrm{Fe}^{3+}$ can form other species except network former. The $\mathrm{NBO} / \mathrm{T}_{\exp }$ also shows that the assumption for $\mathrm{Fe}-\mathrm{O}-\mathrm{Si}$ vibration in the $\mathrm{HF}$ region is appropriate and counts in favor of the possible copolymerization of structural units involving $\mathrm{Si}^{4+}$ and $\mathrm{Fe}^{3+}$ cations. The $\mathrm{Fe}^{3+}$ cations can displace $\mathrm{Si}^{4+}$ cations connecting to $\mathrm{BO}$ in $\mathrm{Q}^{3}$ units, further forming $\mathrm{Si}-\mathrm{O}-\mathrm{Fe}$ bonds. The reaction can be expressed by Eq. (5).

$$
\begin{aligned}
& \mathrm{Si}-\mathrm{O}-\mathrm{Si}\left(\mathrm{in}\left[\mathrm{Si}_{2} \mathrm{O}_{5}\right]^{2-}\right)+ \\
& \mathrm{Fe}-\mathrm{O}-\mathrm{Fe}\left(\mathrm{in}\left[\mathrm{FeO}_{4}\right]^{5-}\right)=2 \mathrm{Si}-\mathrm{O}-\mathrm{Fe}
\end{aligned}
$$

The results of spectroscopic analysis show that the structure of molten slag can be controlled by compositional variation. Depending on the initial basicity and the addition of total iron, the DOP of molten slag can be altered. The DOP affects physical properties of molten slag, and the foaming performance of molten slag can be further modified. The converter slag designer can use the aforementioned information to produce an appropriate slag that can optimize smelting performance to attain the satisfactory metallurgical effect.

\section{Conclusion}

The Raman spectra of $\mathrm{CaO}-\mathrm{SiO}_{2}-\mathrm{Fe}_{x} \mathrm{O}$ system were investigated to identify structural evolution and the DOP of molten slag during the early stage of basic oxygen steelmaking. The typical conclusions are summarized as follows:

(1) When basicity increased from 0.38 to 0.97 and total iron content decreased from 32.77 to 13.26 mass $\%$, increasing $\mathrm{O}^{2-}$ led to the depolymerization of $\left[\mathrm{SiO}_{4}\right]^{4-}$ tetrahedrons from $\mathrm{Q}^{3}$ to $\mathrm{Q}^{0}$ units and the increasing $\left[\mathrm{FeO}_{4}\right]^{5-} /\left[\mathrm{FeO}_{6}\right]^{9-}$ ratio. Because the depolymerization of $\left[\mathrm{SiO}_{4}\right]^{4-}$ tetrahedrons was main reaction, so the DOP of molten slag decreased gradually in this stage.

(2) With further increasing basicity from 0.97 to 1.25 , $\left[\mathrm{SiO}_{4}\right]^{4-}$ tetrahedrons were further depolymerized and $\mathrm{Q}^{3}$ units disappeared. More $\mathrm{O}^{2-}$ ions reacted with $\left[\mathrm{FeO}_{4}\right]^{5-}$ tetrahedrons to form $\left[\mathrm{FeO}_{6}\right]^{9-}$ octahedrons, resulting in the decreasing $\left[\mathrm{FeO}_{4}\right]^{5-} /\left[\mathrm{FeO}_{6}\right]^{9-}$ ratio. The $\left[\mathrm{FeO}_{6}\right]^{9-}$ octahedrons could play the role of modifying silicate structures, and favored the decreasing DOP of molten slag.

(3) The deconvolution of Raman spectra indicated that the existing forms of $\mathrm{Fe}^{3+}$ consisted of $\left[\mathrm{FeO}_{4}\right]^{5-}$ tetrahedron, $\left[\mathrm{FeO}_{6}\right]^{9-}$ octahedron and $\mathrm{Si}-\mathrm{O}-\mathrm{Fe}$ bond of $\mathrm{Q}^{3}$ unit. $\mathrm{Fe}^{3+}$ could act as network former and network modifier, but $\mathrm{Fe}^{2+}$ only acted as charge compensation in the molten slag. 


\section{Acknowledgment}

The authors gratefully acknowledge the National key R \& D Program of China (Grant No. 2017YFC0805100), the National Natural Science Foundation of China (Grant No. 51674069, 51974075) and the Fundamental Research Funds for the Central Universities of China (Grant No. N182506001).

\section{REFERENCES}

1) J. J. PAK and R. J. Fruehan: Metall. Trans. B, 22 (1991), 39

2) K. Gu, N. Dogan and K. S. Coley: Metall. Mater. Trans. B, 48 (2017), 2595

3) Y. Z. Wang, Y. Zhang and W. H. Zhang: The Process and Equipment of Oxygen Top Blown Converter Steelmaking, Metallurgical Industry Press, Beijing, (2001), 33.

4) P. Kozakevitch and T. G. John: J. Met., 21 (1969), 57.

5) K. S. Kim, D. J. Min and J. H. Park: ISIJ Int., 41 (2001), 317.

6) C. F. Cooper and J. A. Kitchener: J. Iron Steel Inst., 193 (1959), 48

7) K. Ito and R. J. Fruehan: Metall. Trans. B, 20 (1989), 515.

8) S. Hara, M. Ikuta, M. Kitamura and K. Ogino: Tetsu-to-Hagané, 69 (1983), 1152 (in Japanese).

9) K. Ito and R. J. Fruehan: Metall. Trans. B, 20 (1989), 509.

10) Y. M. Gao, S. B. Wang, C. Hong, X. J. Ma and F. Yang: Int. J. Miner. Metall. Mater., 21 (2014), 353.

11) C. Feng, J. Tang, L. H. Gao, Z. G. Liu and M. S. Chu: ISIJ Int., 59 (2019), 31

12) B. O. Mysen, D. Virgo and C. M. Scarfe: Am. Mineral., 65 (1980), 690 .

13) D. Virgo and B. O. Mysen: Phys. Chem. Miner., 12 (1985), 65

14) T. F. Cooney and S. K. Sharma: J. Non-Cryst. Solids, 122 (1990), 10.

15) G. A. Waychunas, G. E. Brown, C. W. Ponader and W. E. Jackson: Nature, 332 (1988), 251.

16) G. G. Zhao, D. R. Wu, G. H. Guo, Z. S. Zou and W. Wei: J. Iron Steel Res., 16 (2004), 21 (in Chinese).

17) M. Y. Zhu: Modern Metallurgical Technology, Beijing Industrial Press, Beijing, (2011), 207.

18) B. O. Mysen: Geochim. Cosmochim. Acta, 70 (2006), 2337.

19) C. Rüssel and A. Wiedenroth: Chem. Geol., 213 (2004), 125.

20) T. Osugi, S. Sukenaga, Y. Inatomi, Y. Gonda, N. Saito and K. Nakashima: ISIJ Int., 53 (2013), 185.

21) J. A. Duffy: J. Non-Cryst. Solids, 196 (1996), 45.

22) J. H. Park: J. Non-Cryst. Solids, 358 (2012), 3096.

$23)$ S. Sukenaga, N. Saito, K. Kawakami and K. Nakashima: ISIJ Int., 46 (2006), 352.

24) J. Yang, J. Q. Zhang, Y. Sasaki, O. Ostrovski, C. Zhang, D. Cai and Y. Kashiwaya: Metall. Mater. Trans. B, 48 (2017), 2077.

25) J. Qi, C. J. Liu and M. F. Jiang: J. Non-Cryst. Solids, 475 (2017), 101.
26) R. A. Lange and I. S. E. Carmichael: Geochim. Cosmochim. Acta, 53 (1989), 2195.

27) H. Larson and J. Chipman: Trans. Aime, 196 (1953), 1089

28) V. C. Kress and I. S. E. Carmichael: Mineral. Petrol., 108 (1991), 82.

29) E. J. Jung and D. J. Min: Steel Res. Int., 83 (2012), 705.

30) M. Taylor, G. E. Brown, Jr and P. M. Fenn: Geochim. Cosmochim. Acta, 44 (1980), 109

31) B. O. Mysen, D. Virgo, W. J. Harrison and C. M. Scarfe: Am. Mineral., 65 (1980), 900

32) P. F. McMillan: Am. Mineral., 69 (1984), 622.

33) T. Furukawa, K. E. Fox and W. B. White: J. Chem. Phys., 75 (1981), 3226.

34) F. L. Galeener: Solid State Commun., 44 (1982), 1037.

35) B. O. Mysen, D. Virgo and F. A. Seifert: Rev. Geophys. Space Phys., 20 (1982), 353.

36) P. McMillan: Am. Mineral., 69 (1984), 645.

37) B. O. Mysen, F. J. Ryerson and D. Virgo: Am. Mineral., 65 (1980), 1150.

38) G. Lucazeau, N. Sergent, T. Pagnier, A. Shaula, V. Kharton and F. M. B. Marques: J. Raman Spectrosc., 38 (2007), 21.

39) R. Iordanova, Y. Dimitriev, V. Dimitrov and D. Klissurski: J. NonCryst. Solids, 167 (1994), 74.

40) D. D. Genova, S. Sicola, C. Romano, A. Vona, S. Fanara and L. Spina: Chem. Geol., 457 (2017), 76.

41) D. D. Genova, D. Morgavi, K. Hess, D. R. Neuville, N. Borovkov, D. Perugini and D. B. Dingwell: J. Raman Spectrosc., 46 (2015), 1235.

42) A. D. Muro, N. Métrich, M. Mercier, D. Giordano, D. Massare and G. Montagnac: Chem. Geol., 259 (2009), 78.

$43)$ Z. J. Wang, Q. F. Shu, S. Sridhar, M. Zhang, M. Guo and Z. T. Zhang: Metall. Mater. Trans. B, 46 (2015), 758.

44) Q. Gao, Y. Min and M. F. Jiang: Metall. Mater. Trans. B, 49 (2018), 1302.

45) Y. Min, M. Zhong, J. Huang, C. J. Liu and M. F. Jiang: Steel Res. Int., 85 (2014), 1194.

46) R. G. Duan, K. M. Liang and S. R. Gu: Mater. Chem. Phys., 57 (1998), 92.

47) R. M. Santos, D. Ling, A. Sarvaramini, M. Guo, J. Elsen, F. Larachi, G. Beaudoin, B. Blanpain and T. V. Gerven: Chem. Eng. J., 203 (2012), 239.

48) A. A. Francis: J. Am. Ceram. Soc., 88 (2005), 1859.

49) A. A. Francis: Mater. Res. Bull., 41 (2006), 1146.

50) R. G. Kuryaeva: Glass Phys. Chem., 30 (2004), 157.

$51)$ B. W. Li, S. L. Ou-Yang, X. F. Zhang, X. L. Jia, L. B. Deng and F. Liu: Spectrosc. Spectr. Anal., 34 (2014), 1869.

52) Y. Min, M. Zhong, J. Huang, C. J. Liu and M. F. Jiang: Steel Res. Int., 85 (2014), 1194.

53) Y. Q. Wu, F. C. Jiang, J. L. You, H. Y. Hou and H. Chen: Acta Phys. Sin., 54 (2005), 961.

54) J. C. Bowker, C. H. Lupis and P. A. Flinn: Can. Metall. Q., 20 (1981), 69

55) P. Vadász, M. Havlík and V. Danêk: Can. Metall. Q., 39 (2000), 143. 